\title{
artículos
}

\section{Acción-contemplación: Sermón carmelitano en torno al doble espíritu del profeta Elías. Lectura iconográfica de la iglesia de las Carmelitas Descalzas de Vélez- Málaga y sus pinturas murales (II)}

\author{
Antonio Manuel Peña Méndez \\ Investigador vinculado a la Universidad de Málaga
}

RESUMEN

El siguiente artículo continúa el trabajo presentado en el número anterior del Boletín de Arte, analizando el significado místico, a nivel estructural y ornamental de la iglesia del convento de monjas carmelitas de Jesús, María y José de Vélez-Málaga. Atendiendo especialmente al programa iconográfico de la bóveda y retablo de la Capilla Mayor, así como del Camarín.

PALABRAS CLAVE: Iconografía Cristiana/ Arquitectura Religiosa/ Barroco/ Pintura mural/ Andalucía.

Action-contemplation: Carmelitan sermon concerning the double spirit of the prophet Elías. Iconographic reading of Vélez-Malaga's Carmelite Barefoot church and his wall paintings (II)

ABSTRACT

The following article continues the work presented in the previous number of the Boletin de Arte, analyzing the mystical meaning, to structural and ornamental level of the church of the convent of Carmelite nuns of Jesus, Maria and Jose of Vélez-Malaga. Attending specially to the iconographic program of the vault and altarpiece of the Major Chapel, as well as of the Camarin.

KEY WORDS: Christian Iconography/ Religious Architecture/ Baroque/ Mural Paint/ Andalusia.

Terminada la batalla dispuesta por los frailes jinetes, superando el anillo que forma la cornisa por encima de las pechinas, se eleva la cúpula en la que continúa la metáfora que nos propone el predicador que inspira esta obra y ascendemos del suelo del mundo terrenal al Cielo. En esta bóveda semiesférica se estructuran ocho paramentos trapezoidales ordenados entre idéntico número de nervios que no son estructurales sino simulados por la pintura, que ascienden desde la misma cornisa hasta la clave del cuerpo esférico de la cubierta, donde se enlazan en un fingido entablamento, que orla un rosetón de acantos como un plafón y del que caen unas placas recortadas y cabezas de querubines cuyas alas se metamorfosean en ramos vegetales de hojas carnosas de supuestas yeserías.

* PEÑA MÉNDEZ, Antonio Manuel: “Acción-contemplación: Sermón carmelitano en torno al doble espíritu del profeta Elías. Lectura iconográfica de la iglesia de las Carmelitas Descalzas de Vélez-Málaga y sus pinturas murales (II)", en Boletín de Arte, n 30-31, Departamento de Historia del Arte, Universidad de Málaga, 20092010, págs. 203-221. Fecha de recepción: Enero de 2007. 
Abriéndose como una aparición los paramentos con forma de trapecios comprendidos entre tales simulados arquitectónicos, se ven como si de una cúpula acristalada se tratara y nos mostrara surgiendo entre una apoteosis de cúmulos nubosos, una corte de grandes figuras del Santoral, todos fundadores de órdenes religiosas de la Iglesia Católica cuyos atributos distintivos entrevemos con mucha dificultad en los ángulos inferiores, donde también actúan parejas de ángeles en diversas posturas y gestos que la oscuridad y deterioro de las obras no permiten analizar mejor, pero nos podrían indicar la parte activa y comunicativa de cada representación frente al estatismo de las figuras principales. De forma que usando este recurso del "trompe l'oeil" se intenta producir en el espectador un efecto de realidad, engañando nuestras retinas haciéndonos creer que se trata de una arquitectura real con verdadero relieve completando estas intenciones de apariencia con las yeserías fingidas ya tratadas, y que los personajes que aparecen envueltos en nubes forman parte de la realidad que experimentamos. En suma, se trata de una "trampa para el ojo", que por medio del ilusionismo de los frescos se siente inmerso en ese mundo sobrenatural donde nota la presencia física de lo sagrado.

El artista quiere hacernos perceptible con claridad, con autenticidad figurativa, ese espacio ideal que se cuela en nuestro mundo, pues pretende que ese territorio desprovisto de materia palpable propio de lo divino, aparezca alcanzable a la comprensión del hombre de la calle que necesita creerlo verdadero ${ }^{1}$. De esta forma toman cuerpo en los segmentos de la bóveda las ocho efigies tratadas con intención realista, según ya indicamos en referencia a la composición de lugar ignaciana, pero haciendo de ellas estatuas de santos, esto es, que son representadas por el pintor como si de obras escultóricas se tratara, haciendo que las imágenes aparenten tomar cuerpo como hace por ejemplo Zurbarán creando en sus lienzos lo que parecen tallas de retablos o estatuas de piedra policromada ${ }^{2}$, porque los fieles y devotos de la época barroca practicaban una religiosidad más exteriorizada que profunda, muy dependiente de los sentidos y menos intelectual, aunque profundamente sincera.

Estos santos parecerían estar dispuestos como en los nichos de sus altares, igual que las imágenes de talla, que fueron y siguen siendo fundamentales en la religiosidad popular y que llenan templos, parroquias, camarines y ermitas de toda España. Poseían para la mentalidad del hombre barroco un valor taumaturgo, con poder para realizar milagros y propiciar curaciones. Además como típicos santos en apoteosis, están levitando ingrávidos sobre un lecho nuboso con el fondo de luz resplandeciente y se dirigen hieráticos con la vista hacia el suelo buscando encontrar la mirada de los fieles que imploran su mediación.

Distinguiremos para empezar por su proximidad a las bóvedas de la nave del templo a San Ignacio y al fundador de los Trinitarios San Félix de Valois. El jesuita porta como atributo en su siniestra la custodia con el anagrama jesuítico, mientras

1 GALLEGO, J.: Visión y símbolo..., op. cit., pág. 253.

2 Ibídem., pág. 245. 
con gesto similar al que emplearán el resto de sus compañeros celestiales, y tal como él mismo recomendó en sus Ejercicios Espirituales, dispone su mano derecha abierta sobre el pecho, comunicando con ese lenguaje gestual la entrega de sí mismo y su actitud de oración y súplica de misericordia, tal como son interpretados estos movimientos de manos con los cuales las gentes de los siglos XVII y XVIII eran tan dados a comunicarse, influidos por el lenguaje corporal propio del teatro y las representaciones de ópera que frecuentaban ${ }^{3}$. Por su lado el Santo trinitario, con gesto idéntico sobre el pecho, reclama con la otra mano la atención del público como solicitando se le tome como ejemplo, mientras a sus pies en el ángulo inferior derecho intuimos el ciervo con el que se relaciona su iconografía.

Continuaremos encontrando junto al santo de Loyola al Poverello de Asís, San Francisco y opuesto a San Félix, el programa sitúa a Santo Domingo de Guzmán, los dos pilares de la iglesia medieval al fundar sus respectivas órdenes mendicantes que reactivaron y ensalzaron la espiritualidad de aquellos duros tiempos. El santo predicador porta una rama florida de lirios mientras su otra mano nos habla con gestos simulando estar en actitud de predicar como es propio de su orden. Como singularidad en el conjunto, mientras el resto se presentan levantados y en comunicación con el público, el santo franciscano por su parte surge entre el torbellino de nubes arrodillado y abrazando el crucifijo en el que concentra la expresión de su rostro, interiorizando su experiencia y recogimiento místico, sin percatarse de nosotros que le observamos desde la Tierra.

Flanqueando a los anteriores santos mendicantes, nos encontramos ante dos fundadores que vivieron por el contrario en los primeros siglos medievales, San Agustín y San Benito de Nursia. El primero aparece con el sencillo hábito de los agustinos ceñido por una correa de cuero, insistiendo como venimos percibiendo en el valor de la austeridad y pobreza que debe ser propia de los religiosos y no con su faceta más habitual de obispo o doctor de la Iglesia. Presenta sobre su derecha el corazón ardiendo que tiene como atributo. El benedictino viste su negro y amplio hábito de mangas muy anchas y capucha, con la cruz abacial al pecho, mientras en el suelo se puede apreciar el báculo de su dignidad.

Presidiendo este ilustre santoral y abriendo paso desde la cúpula a la bóveda que cubre la capilla mayor, nos encontramos a las dos figuras más señeras del Carmelo, San Elías y Santa Teresa de Jesús, que son asociados intencionadamente en esta situación del discurso programático del templo, compartiendo sitio de honor en la gloria con los otros grandes fundadores, el uno como origen primigenio de los carmelitas en la antigüedad bíblica y ella por haber retomado aquella pretérita observancia que empezaron los padres del desierto en torno al Monte Carmelo, por lo que asume papel de refundadora de la orden al poner en marcha su reforma descalza. Este deseo incluso obsesivo del Carmen por remontar sus orígenes al

\footnotetext{
3 Palomino, que según el profesor Julián Gállego sigue a Ripa, en el capítulo IX del Tomo $2^{\circ}$ de su Museo codifica los ademanes, posturas y gestos empleados en el arte explicando la retórica visual que suponían sus significados.
} 
Antiguo Testamento, envolviendo su fundación de misterio por acoger al profeta Elías como fundador quien dio la primitiva regla a su discípulo San Eliseo, ha sido una constante en esta religión. Dicha regla siguió perviviendo en los eremitas míticos que habitaron las grutas y soledades de aquella colina del Carmelo en la tierra de Palestina, cercana a Jaifa. Esta primitiva vida cenobítica carmelita llegó al Nuevo Testamento de la mano de esos monjes, entre los que Cristo encontraría a su primo San Juan Bautista, extendiéndose por ejemplo a tierras egipcias de la mano de los padres del desierto San Antonio y San Pablo, encontrándola luego los cruzados que la harían llegar a Europa a su regreso de Oriente.

Toda esta historia mítica fue muy atacada por las investigaciones bolandistas que las demostraron inciertas en 1670 retrasando su nacimiento al siglo XII, con lo que se propició un tremendo escándalo y confrontación que debió ser acallada por Inocencio XII ${ }^{4}$. A pesar de toda esta polémica, la tradición carmelitana que enraizaba a la orden con aquellos monjes eremitas imitadores y discípulos del ejemplo eliánico, continuó haciendo presente la figura del profeta al que siguen asumiendo como inspirador de su vida religiosa y lo veneran como padre espiritual del Carmelo.

Su iconografía que sigue la representación veleña, presenta generalmente muy pocas variantes, vistiendo al profeta como un ermitaño del desierto con túnica de pieles de colores pardos envuelto en capa clara también de pellejo de animal. En nuestro cuadro no porta el libro ni la torre que suele asignársele como símbolos de su carácter de fundador y redactor de la primera regla, pero sí se nos muestra con expresión enérgica e incluso furiosa, blandiendo una refulgente espada de fuego con la que nos revela su potente defensa del único y verdadero Dios de Israel, vencedor y destructor de las otras deidades paganas. Pintan al Profeta en la cúpula de Vélez con fiera actitud, apelándonos furibundo, con su espada en alto para que desterremos cualquier culto o idolatría de falsos dioses, que siempre estamos dispuestos a venerar desde la frágil y débil naturaleza humana.

Si la presencia de Elías nos impela a actuar con vigor reconociendo quién es el Dios verdadero en contra de los enemigos de la fe, Santa Teresa asume en esta segunda aparición en la iglesia, la otra vertiente del Espíritu de Elías. Junto a la acción que enseña el Profeta, se representa la contemplación de la mano de la mística castellana. La Madre Fundadora surge así de entre los nimbos sorprendida por los rayos de luz que abren los cielos, y por ese hueco ve a Dios, pues ese fulgor es "luz tan diferente a la de acá" 5 .

En la pintura española no cabe duda que la luz se empleó por los artistas barrocos con una evidente carga simbólica y los sistemas de iluminación que plasmaron también encierran un lenguaje metafísico. Especialmente en estas ocho representaciones de la cúpula se recurre a un ejercicio lumínico muy empleado por parte de los pintores de este siglo. Aparece una fuente de luz cenital que abre las tinieblas

4 SEBASTIAN, S.: Contrarreforma y Barroco. Lecturas iconográficas e iconológicas, Alianza Editorial, Madrid, 1981, págs. 239-240.

5 TERESA DE JESÚS: Vida, capítulo XXVIII, en Obras completas, Madrid, 1984. 
o torbellino nuboso, cayendo como columna sobre las cabezas de las figuras de los santos. Es una luz sobrenatural, misteriosa, luz de revelación que hace trizas la oscuridad y toca la frente de cada personaje, que por el contrario y en realidad son iluminados en la composición desde un foco indeterminado en un primer plano.

Por otro lado los ocho fundadores aparecen entre formas de nubes que asemejan más riscos o rocas de una caverna que vapores, volviendo a ver aquí como se emplea con lenguaje alegórico la gruta eremítica, como simbolismo del vacío del mundo y espacio de anacoretas que encuentran en su estado de soledad y abandono la revelación de la Gracia6.

La santa es la única de las figuras del grupo que levanta la mirada y pierde la vista en lo profundo del infinito cielo abierto, sin comunicarse visualmente con los fieles ni dirigirse a nosotros. Está ajena al mundo, presa de la presencia divina y despojada completamente de toda atadura terrena o relación humana, aunque nos sigue hablando con sus manos requiriendo suavemente nuestra atención con la mano izquierda e informándonos con la otra abierta sobre el pecho que está orando y por medio de su plegaria mantiene el enlace espiritual con su amado, con Cristo.

La espiritualidad de los descalzos, plasmada principalmente en los escritos de esta santa y San Juan de la Cruz, plantea una vida espiritual en búsqueda permanente de Jesucristo, con el que se entabla una relación marital, un enamoramiento de Jesús que está siempre con cada uno de nosotros. Santa Teresa en el cuadro se muestra absorta, orando ensimismada en su trato con Dios, y así se va introduciendo en el fondo abisal del misterio cristiano, escondido en lo más recóndito del alma, del castillo interior, y allí habita la divinidad.

Como se indicó líneas arriba, nos presenta el pintor a Santa Teresa como modelo de la contemplación, incidiendo sutilmente en este acto con la colocación del tintero y dos plumas en los bajos de la representación. Parecen como olvidados en una esquina, al filo de la cuadrícula rectangular que cierra cada paramento mural y hace las veces de mesa. Con ello se deja muy clara la gran actividad literaria de la religiosa, pero se evidencia que junto a toda esa labor y trabajo incansable realizado a lo largo de sus días, es el recogimiento sobre ella misma para el encuentro místico, lo que se quiere resaltar y enseñar.

La disposición compositiva de la cúpula sería pues un aparato de corte casi teatral, de ejercicio de ilusionismo óptico, por medio de la cual el maestro pintor pone su oficio al servicio del predicador para, por medio de la visión celeste, conseguir de forma aparatosa introducir un espacio dentro de otro, más aún, meter un espacio ideal en uno real. Y esto responde a la concepción del universo que poseen los españoles de la Edad Moderna7, para los que con toda claridad son plenamente conscientes de

6 GÁLLEGO, J.: Visión y símbolo en la pintura española del Siglo de Oro, Cátedra, Madrid, 1984,págs. 243244. En esta obra pone entre otros como ejemplos de todo lo citado, la oscuridad en la que Velázquez o Carreño de Miranda envuelven las estancias del Alcázar de los Austrias, más como morada del desierto donde vive la reina-monja Doña Mariana.

7 GÁLLEGO, J.: Visión y símbolo..., op. cit., págs. 252-253. 
la existencia y realidad de esos dos mundos yuxtapuestos, como ya se ha mencionado, en continuo y permanente contacto. El uno humano o inferior de apariencia sólida, que sería la vida real y el otro superior o celeste y que no se percibe habitualmente, aunque siempre esté presente, pero que sólo en concretas ocasiones se hace visible como en este momento en la transparencia de los paños de las bóvedas.

Estos paños repiten una composición similar para las ocho figuras del santoral que muestran, con la imagen de pie en el centro materializándose ante nuestros ojos envueltos en pomposas nubes que se abren a los lados para dejar caer una columna de luz irradiada desde el tondo central que hace de clave de la cúpula.

Insistimos en como la luz es clave en nuestra pintura de los siglos XVII y XVIII y los artistas la plasman como aquí, cortando las tinieblas, aportándole de ese modo un sentido religioso y celeste envolviendo a los personajes. Los grandes maestros la usaron con magistral soltura cuando quisieron apuntar de un espacio real su carácter divino, y mucho más en esta iglesia carmelita, donde el sentimiento místico se tiene tan presente por medio de las experiencias y visiones de Santa Teresa ${ }^{8}$.

Para reforzar esta naturaleza sobrenatural y celeste que se abre sobre la feligresía, la base inferior de cada tramo trapezoidal está frecuentada por los mencionados angelitos que, o bien juegan o sostienen los atributos de cada santo o se retuercen y actúan con gestos, que con mucha dificultad acertamos a distinguir por lo oscurecido y deteriorado de estas partes de los frescos, pudiendo incluso estar mostrando alguna cartela o filacteria que sospechamos pudiera esconderse bajo los recuadros rectangulares en los que se apoyan las composiciones 9 .

Sobre la autoría de las pinturas, sin una confirmación documental solo podemos sumarnos a las atribuciones que otros autores aportan sobre la paternidad de la obra mural que tratamos en Vélez. De una parte en el Inventario artístico de Málaga y su provincia solo se apunta la filiación con la escuela granadina del siglo XVIII. Por otro lado Agustín Clavijo en su tesis doctoral dedicada a la pintura barroca malagueña afina algo más, pues entronca el conjunto igualmente con el círculo de Granada datando las pinturas en el primer tercio de la centuria. Por sus rasgos estilísticos parecen recordarle los trabajos de Diego de la Cerda10, única figura digna de mención según el mismo autor en todo el panorama pictórico de la Málaga del último barroco $^{11}$, del que tenemos bien documentada su intensa actividad como maestro

8 Ibídem., págs. 254 y 163.

9 Nos induce a expresar tal hipótesis tanto el estudio dificultoso de las posturas que presentan los ángeles, como la similitud que vemos en composiciones muy cercanas de templos de otras ciudades como las de la bóveda de la capilla sacramental de la parroquia de S. Pedro de la capital malagueña, atribuida igualmente a Diego de la Cerda en torno a 1720, o por ejemplo las pinturas de la iglesia carmelita del Buen Suceso de Sevilla pintadas por Andrés Rubira en ese mismo siglo o en el lienzo del Palio de San Elías de los Padres Carmelitas cordobeses de San José y San Cayetano. AA.VV.: Decor Carmeli. El Carmelo en Andalucía. Córdoba, 2002.

10 CLAVIJO GARCÍA, A.: La pintura barroca en Málaga y su provincia, Tesis doctoral, Universidad de Málaga, Ejemplar microfilmado, 1993, pág. 1843.

11 CLAVIJO GARCÍA, A.: "La pintura malagueña del Barroco tardío (1745-1851)", en Boletín de Arte, $n^{\circ} 6$, Universidad de Málaga, 1985. 
pintor en la primera parte del siglo y su muerte en $1745^{12}$ año de terminación de la iglesia carmelita de Vélez, con lo que pudo iniciar y plantear la obra que concluirían sus discípulos más tarde, siempre y cuando el edificio no fuera consagrado en dicha fecha completamente decorado.

la bóveda de la Capilla Mayor. Gloria eterna donde habita DIOS Y SUS EJÉRCITOS.

Adentrados en ese pozo hondo, esa fortaleza profunda que es la morada del alma humana, llegamos a la cueva que prefigura la capilla mayor y como acabamos de decir, en este lugar, superados los pecados y vencido el cuerpo, nos impregnamos de la presencia de Dios, pues en esta bóveda se pinta la Santísima Trinidad.

En nuestra opinión en la capilla mayor de esta iglesia de Vélez, sus promotores tuvieron presente la búsqueda del retiro en soledad como ejercicio de piedad para la vida contemplativa tan fuertemente arraigado en Santa Teresa. Ella siempre aspiró al eremitismo, aunque a las monjas, por su condición de mujeres, la Iglesia siempre les tuvo vedado este estilo de vida, materializado en el Carmelo en los "Desiertos"13, que siempre fueron masculinos. Por eso el templo plantea la capilla mayor como un espacio restringido, reduce su planta y baja su altura, para disponer un recinto más recogido, intensificando su papel simbólico como enclave para la reserva de la eucaristía y dotándole de una fuerza o significación de raigambre íntima y mistérica para la práctica de la veneración y estación ante el Santísimo, que se hace presente y habita en él ${ }^{14}$. Adquiere por tanto esta capilla cierta semejanza con una gruta de ermitaño, como una cavidad para rezar en la intimidad junto al Señor Sacramentado. No en vano el coro de la comunidad abre su reja y comulgatorio en uno de sus lados, lo más cerca posible al tabernáculo eucarístico.

Por todo ello, se nos vienen a la mente diversas referencias a estos retiros eremíticos en los escritos de la Santa Madre como cuando dice a sus hijas: "El estilo de vida que pretendemos llevar es no sólo de ser monjas, sino ermitañas"15, o cuando en las Constituciones les recomienda en la huerta "hacer ermitas para que se pueda apartar a oración, conforme lo que hacían nuestros santos padres"16. A pesar de que con los años la comunidad de Vélez ha ido cediendo a la ciudad parte del terreno ocu-

12 LLORDEN, A.: Pintores y doradores malagueños, Ávila, Ediciones del Real Monasterio del Escorial, 1959, págs. 286-290.

13 RODRIGUEZ MARIN, F. y MORALES FOLGUERA, J.M. "La sacralización del espacio rural. Las ermitas del desierto carmelita de Ntra. Señora de las Nieves (El Burgo, Málaga)", Cuadernos de Arte e Iconografía, VI/12, 1993.

14 El padre Silverio nos refiere a este propósito una semblanza de la Madre Manuela Mariana de San José, una de las religiosas fundadoras donde se dice de ella que "pudo entregarse con mayor asiduidad a la vida interior cuando, habiendo quedado impedida por diversos achaques que la venían molestando, pasaba largas horas en compañía de Jesús en el Sagrario".

15 TERESA DE JESÚS: Camino de perfección, 13,6, en Obras completas, Madrid, 1984

16 TERESA DE JESÚS: Constituciones, cap.6, n¹7, en ibídem. 


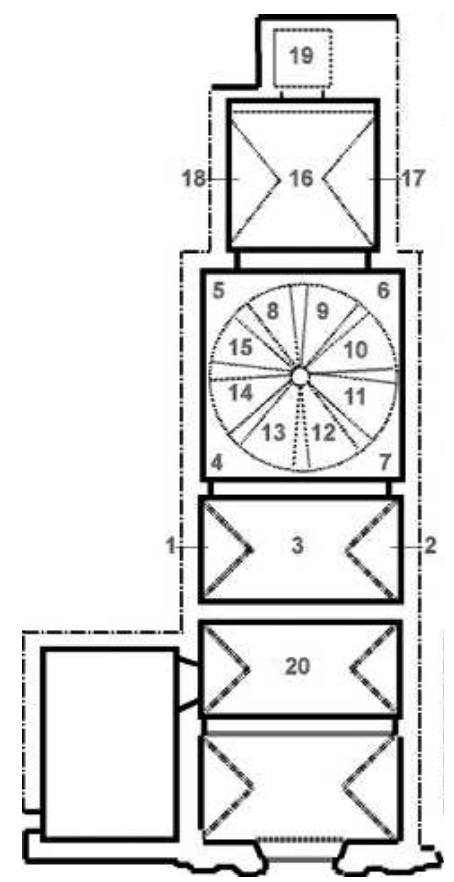

1. Planta de la Iglesia conventual de las carmelitas (Vélez-Málaga). pado originalmente, reduciendo su perímetro, aún mantiene celosamente esta práctica tradicional del carmelo teresiano, con varias ermitas en la huerta.

En el arte español de este período y con especial implicación en la pintura, la gruta tiene un carácter simbólico, más aún que escenario o espacio figurativo para una representación. La caverna viene a encarnar el espacio de ultratumba, indica también un estado de renuncia, de entierro voluntario, de sepultura en vida, que es lo que hace el ermitaño, el asceta. Estamos hablando de la cueva como lugar sin luz, como la noche oscura del alma de San Juan de la Cruz para quien sólo "la fe, en noche oscura, dé luz al alma, que está a oscuras"17.

Por tanto desde el centro de la bóveda de cañón que cubre el espacio donde tiene lugar la celebración de la liturgia eucarística, iluminan la escena las tres entidades de la Trinidad, rodeados de una corte de querubines, angelitos y ángeles mancebos que acompañan su presencia soberana y son testigos de cómo el Dios uno y trino, dispensa su bendición abrien-

do el oscuro abismo, para tomar forma de pan y vino en la consagración durante la santa misa para alimentar a los hombres.

La Historia del Arte no ha tenido fácil, como tampoco la teología, el representar un Dios que es a un tiempo tres y uno solo, expresando con idéntica fuerza la unidad y la pluralidad que encierra este misterio ${ }^{18}$. Entre la diversidad de sistemas que el imaginario artístico cristiano usó tanto en Oriente como en Occidente, en el caso estudiado se recurre a la fórmula antropozoomorfa que cobra cada vez más difusión desde las condenas que se vierten en Trento sobre determinados modos de representar el tema ${ }^{19}$.

La composición individualiza a cada una de las tres personas trinitarias, diferenciándolas tanto por su edad, forma y atributos. De tal modo nos encontramos con un Dios Padre, primera persona, barbado, con larga túnica y envuelto en manto que inflama el viento divino, bendiciendo con su diestra mientras apoya la siniestra en un globo terráqueo, simbolismo de su carácter de creador del mundo. Sentado junto a

17 GALLEGO, J.: Visión y símbolo..., op. cit., págs. 243-244.

18 RÉAU, L.: Iconografía del arte cristiano. Iconografía de la Biblia. Antiguo Testamento, T.1, vol.1, pág. 37.

19 Ibídem., pág. 45. 
Él, a su mismo nivel la segunda persona, Dios Hijo Jesucristo bendiciendo también, abraza la cruz como quien porta un estandarte de victoria, pues como Hombre, Jesús se sacrificó en ese patíbulo para salvación de la Humanidad y como Dios resucitó a la vida eterna. Entre ellos, sobre sus cabezas que miran a la Tierra, la tercera persona, que en forma de paloma representa al Espíritu Santo, formando con ellas una composición triangular simbolizando la tríada.

Esta composición geométrica que subraya la diversidad de la terna divina, se conjuga con la circunferencia imaginaria que componen los cuerpos de las figuras, inscribiendo así el círculo en la obra como expresión de la indisolubilidad de la Divinidad.

La corte angelical aporta a la escena algunos matices, pues no pueden faltar en la pintura española que figure el espacio ideal de una visión celestial. En los ángulos superiores surgen cabezas aladas de querubines, que sonrientes y juguetones, flotan animando las nubes demostrando la naturaleza gloriosa de estas y su ingravidez 20 . Por su lado, el segmento inferior de la escena diríamos que convierte a los dos ángeles jóvenes en cabalgaduras aladas sobre las que sobrevuelan los cielos tanto el Padre como el Hijo, pues recuerdan las Nikés clásicas en las que los difuntos emperadores romanos eran elevados al mundo celestial de los dioses.

Entendiendo la capilla mayor, como el espacio simbólico de la morada divina, en la que está físicamente presente Jesucristo en forma consagrada en el reservado sagrario, y pintado en su naturaleza trina en el techo, como Soberano del universo, se rodea de sus cortesanos y servidores. Por eso a ambos lados encontramos dos obras apaisadas que decoran los lunetos laterales de la capilla, en los que no podían aparecer otros más que arcángeles, en este caso San Miguel y San Gabriel.

Si en el cuadro de la Santísima Trinidad que centra el conjunto, entendíamos a Dios entronizado, majestuoso, como los grandes reyes orientales a los que sirven y acompañan toda su corte 21 , en el aparato de esta monarquía celestial son imprescindibles el capitán de las huestes del cielo, el guerrero y archiestratega Miguel, así como el emisario y heraldo por el que habla Dios, San Gabriel. Estos personajes celestes forman parte de la penúltima de las nueve jerarquías en las que se dividen los órdenes que conforman la corte celestial, tal como lo dejó por escrito Dionisio Areopagita, en su obra "Jerarquía Celeste", y de ellos habla la Biblia en el libro de Daniel22.

Aunque en las Iglesias orientales y bizantinas las jerarquías angélicas son muy representadas, la Iglesia Romana no los fomenta demasiado, limitando en el Concilio de Letrán en el 746 el culto a los tres arcángeles más conocidos, Miguel, Rafael y Gabriel, y decayendo su representación enormemente con la Contrarreforma. A pesar de ello el barroco hispánico peninsular 23 y el arte virreinal ${ }^{24}$,

20 GALLEGO, J.: Visión y símbolo..., op. cit., pág. 254.

21 RÉAU, L.: Iconografía del arte cristiano... op. cit., pág. 53.

22 Ibídem., págs. 62-63.

23 RUIZ ALCÓN, Ma T.: “Los arcángeles en los monasterios de las Descalzas Reales y de la Encarnación”, Reales Sitios, año XI, $n^{\circ} 40,1974$, págs. 45-56

24 MESA, J. y GISBERT, T.: "La serie de ángeles en la pintura virreinal”, Revista aeronáutica, № 31, Dic. 1973, La Paz, Bolivia. 
dedicará amplias series con los siete arcángeles, aunque siempre serán los tres canónigos los más representados. Encontramos por eso infinidad de comunidades religiosas de todas las órdenes encargando en los siglos XVII y XVIII extensas secuencias representando ángeles ${ }^{25}$ y hacia los que el Carmelo siente especial predilección, dedicándoles su atención en diversas de sus iglesias y claustros ${ }^{26}$.

En nuestra iglesia podrían haber estado si especulamos con que los dos cuadros desaparecidos que estaban en la misma capilla mayor, y por debajo de los que tratamos, y los tres de forma oval que se observan en las fotos de Temboury en el arco toral que abre la capilla, estuvieron dedicados a ellos, como ocurre en la espléndida serie del convento de religiosas descalzas de la misma orden en la villa cordobesa de Aguilar de la Frontera, considerada una auténtica lección o tratado de angeleología 27 . Suponiendo que nuestra intuición respondiera a la realidad, cosa bastante improbable de confirmar, los muros de la capilla mayor presentarían a los cuatro arcángeles Miguel, Gabriel, Rafael y Uriel como nos relata el libro de Enoc, montando guardia ante el trono divino ${ }^{28}$ y en el frontal del gran arco que abre la capilla, asumiendo las veces de arco triunfal o portada palaciega, estarían en los tres paños ovales los arcángeles restantes que forman esta jerarquía 29 .

Dejando aparte el terreno de la especulación, en el análisis formal de los arcángeles conservados, sus figuras caen desde el cielo en composición diagonal al espacio del cuadro, llevando las alas extendidas pareciendo planear y dando una gran sensación de realismo en la acrobacia aérea por medio de la agitación y vuelo de las ropas, y sobre todo de los mantos que los envuelven, agitados con fuerza por el aire.

Tanto el santo guerrero como el pacífico mensajero se aprestan inclinados sobre el ángulo inferior que apunta al altar, en cuyo rincón se esconden sendas figuras con las que interactúan cada uno en su respectiva escena. En el ejemplo de San Gabriel nos ha sido imposible distinguir de quien se trata por lo alto y oscuro de la obra. Sin embargo en San Miguel se vislumbra como con tesón alancea el cuerpo caído del Diablo, que se abrasa entre llamas, arrastrándose mientras intenta zafarse de la pulla de su rival. Esta representación nos recuerda mucho el enorme lienzo pintado por Juan Niño de Guevara para el altar del crucero sur de la Iglesia Mayor malagueña junto a la Puerta de los Abades que pudo tomar como modelo nuestro autor dieciochesco, que si bien resulta ser Diego de la Cerda como luego se verá, también

25 LARA ARREBOLA, Fco.: "Bernabé de Ayala y la serie de ángeles del Monasterio de San José y San Roque de Aguilar de la Frontera", BRCA, 1980, págs. 199-200.

26 La iglesia de Carmelitas de Viena presenta un ciclo de 1435 dedicado a la Virgen presidiendo las nueve jerarquías celestiales, o en el Carmelo de Palermo son los siete arcángeles los que custodian a la Trinidad en un fresco de su iglesia de San Ángel de 1516. En Andalucía citamos el conjunto pintado para el convento del Santo Ángel de la Guarda de Sevilla realizado por Polanco sobre 1649.

27 LLAMAS VELA, A.: "Iconología angélica del Monasterio de San José y San Roque de Aguilar de la Frontera" en ARANDA DONCEL, J.: II Encuentros de Historia Local. La Campiña, Córdoba, 1994.

28 RÉAU, L.: Iconografía del arte cristiano... op. cit., pág. 67.

29 Los nombres de estos seres varían según las fuentes. Siguiendo el Testamento de los Doce Patriarcas serían Ragüel, Saraqael y Remeiel. Louis Reau apunta otras diversas denominaciones. RÉAU, L.: Iconografía del arte cristiano... op. cit., págs. 65-66. 
tiene cuadros en la catedral ${ }^{30}$.

En Satán difícilmente acertamos a distinguir sus monstruosas facciones, algo más claramente advertimos sus pequeñas alas membranosas de criatura nocturna y su cuerpo humanoide muy tostado contrastando con la piel clara del arcángel. Este viste al modo militar romano de corte clasicista con una túnica corta sobre la que se ciñe un peto metálico y calza unas grebas por debajo de las rodillas. San Gabriel por su parte viste también a la antigua pero sin apariencia militar, con túnica más larga con mangas anchas que caen hasta medio brazo, y abiertas desde el muslo para mostrar las piernas. Los colores en él son claros (celestes, rosa, blanco) mientras el guerrero gasta tonos oscuros (azules, rojos y pardos).

Aunque San Gabriel es el ángel pacífico, portador y heraldo de la buena noticia del nacimiento de Jesús, en esta representación le intuimos cierto aire guerrero emparejando con su marcial compañero, pues en lugar de portar el mérilo o bastón de mensajero, embraza con su izquierda una adarga o escudo ovalado blanco, ribeteado en oro con el anagrama del Ave María con una corona en rojo, tras el que lleva la vara de azucenas. Con el índice de la mano derecha señala el símbolo mariano para significar el mensaje mandado por Dios, arrojándose impetuoso sobre la supuesta figura oculta por la suciedad del tiempo, a la que acosa. Tal vez podamos ampliar la interpretación de esta iglesia, abundando en su significado indicando, siguiendo a Réau ${ }^{31}$, como ambos seres angélicos adquieren en algunas iglesias la función de propíleos o guardianes de puertas. Estarían protegiendo del Demonio el acceso al camarín cuya fachada y entrada no sería otra que el retablo, pero además la figura de Miguel sobre todo nos advierte su calidad de santo conductor de los espíritus difuntos al Juicio Final, pues ejerce de pesador de las almas ${ }^{32}$. Igualmente concuerda con su recurrente oficio de guardián a las puertas del camarín donde habita la Reina del Cielo, la Virgen y se nos antoja emulando al San Miguel a la entrada del jardín edénico de un grabado de 1632 de Gregoire Huret que nos presenta Rodríguez de la Flor en su Península Metafísica 33 .

Efectismo y teatralidad barroca. El retablo de la Capilla MAYOR.

Con esto penetraríamos en el fondo y culminación del programa que encierra alegóricamente el templo, que sería la Virgen María, concebida como sagrario en cuyo vientre habitó el Salvador o como trono en el que se sienta Dios Hijo. Ella es

\footnotetext{
30 CAMACHO MARTíNEZ, R. y otros: Guía Histórico Artística de Málaga, Edt. Arguval, Málaga, 1997, págs. 89,90 y 93

31 RÉAU, L.: Iconografía del arte cristiano... op. cit., pág. 76.

32 Ibídem., pág. 68.

33 RODRÍGUEZ DE LA FLOR, F.: La Península Metafísica. Arte, Literatura y Pensamiento en la España de la Contrarreforma, Edt. Biblioteca Nueva, Madrid, 1999. San Miguel guarda la entrada al Paraíso y a sus pies aparece la leyenda Custos est divitis Horti.
} 
protagonista final de nuestra experiencia de ascenso místico que finaliza en el testero frontal de la capilla principal que aparecía oculto por una recargada maquinaria retablística barroca de madera dorada que los destrozos de los lamentables inicios de la guerra del 36 convirtieron en cenizas, siendo su actual sustituto una insípida obra del año 1952, que en nada recuerda, salvo en las advocaciones de las tres imágenes que enmarca, al mueble dieciochesco. De nuevo el archivo fotográfico Temboury nos regala con cierta calidad poder analizar y leer su arte, completando nuestra interpretación en conjunto de la iglesia carmelita.

Como más abajo se indicó, retablo y camarín deben leerse juntos y a su vez como colofón a la propuesta de ejercicio espiritual que se nos propone en todo el conjunto del templo que ya dijimos emplea su traza longitudinal como concepción espacial en la que está implícita la direccionalidad. La planta rectangular se emplea como espacio camino orientado hacia el retablo y altar mayor, que al incorporar en su testero el camarín, enfatiza la orientación, pues estamos ante un diseño de espacio dinámico que nos impulsa a marchar atraídos por la imagen que habita al final.

El retablo que ocultaba según dijimos en su totalidad el testero de la capilla, se ideó como una monumental tramoya barroca donde las formas tectónicas y los elementos o diseños arquitectónicos han perdido su función sustentante u organizativa del edificio retablístico, para dejar paso al triunfo de la exuberancia de la talla, creando con ello una quimera refulgente, mezcla de espejos, doseles, cortinajes, roleos, guirnaldas, medallones o finos estípites sin funciones sustentantes ni lógica orgánica, al servicio de un delirio decorativista o máquina de maravillas. En palabras de Gallego y Burín sobre el retablo barroco churrigueresco... "un puro temblor de oros ${ }^{34}$.

Se encuadra nuestro retablo en la segunda etapa de la retablística barroca hispana denominada castiza, que abarca la amplia cronología de la segunda mitad del siglo XVII perdurando según las regiones bastante en la siguiente. Aquí se concreta en el uso como soporte del estípite, invadido luego todo por la desbordante profusión decorativa de vegetales, placas y todo tipo de invenciones. Sigue la estela estilística de las obras salidas de los talleres de la escuela de Pedro Duque Cornejo materializadas en la utilización de un sin fin de placas muy recortadas y superpuestas, de contornos sinuosos, destacándose las cornisas ondulantes ${ }^{35}$ para lo que pudieron servir de modelo los retablos de la iglesia jesuítica de San Luis de los Franceses en Sevilla y especialmente la disposición de doseles y cortinajes dispuestos en el retablo granadino de la Virgen de la Antigua en la catedral. Igualmente pensamos que este perdido retablo de Vélez no descartó préstamos de los diseños del gran maestro del arte del retablo en Andalucía, el granadino Hurtado Izquierdo, guardando ciertas similitudes con su obra del templo mayor de Granada en la capilla de Santiago y en especial la maestría de este artista para imbuir sus creaciones

34 GALLEGO Y BURIN.: El barroco granadino, Granada, 1956, pág. 9.

35 RODRÍGUEZ G. DE CEBALLOS, A.: "El retablo español", Cuadernos de Arte Español, № 72, Madrid 1992 
de efectismo teatral, confundiendo al espectador entre lo real o ilusorio, haciendo surgir a los santos de entre las bambalinas provocando la sorpresa ${ }^{36}$.

Con este tipo de construcciones, donde lo escultórico ha copado el lugar de lo constructivo y las formas han sido distorsionadas y modificadas hasta deconstruirlas sin canon alguno, agobiadas de masas y elementos decorativos, se pretende dar un golpe de efecto definitivo al impresionado observador, que, impregnado de todo el arrebato espiritual emanado del resto del edificio, caería absorto y sobrecogido ante tal despliegue de irracionalidad y alejamiento de su comprensión cotidiana asumiendo en esa copiosa riqueza, la luz cegadora de lo divino. Pues así el hombre del barroco hispano, toma conciencia de su limitación asumiendo lo infinito, y pensando que el mundo es en realidad un inmenso vacío, de tiniebla desnuda, que atrae de inmediato la presencia de la divinidad, como si Dios colmatara la nada ${ }^{37}$, tal como escuchamos a Osuna escribir en su Tercer Abecedario "Así el corazón vacío de lo mundano atrae a Dios que ocupe y supla su falta" 38 , podemos entender todo este horror vacui que hace abarrotar los edificios y templos barrocos como el nuestro de sus excesos y delirios de decoración, como el Todopoderoso lo llena todo.

Semejantes artilugios cargados de sentido religioso con toda su exhuberancia y exceso, desaparecieron tristemente de los templos veleños en la Guerra Civil por lo que no nos resistimos a incitar la comparación entre al menos tres de ellos que se realizaron en décadas cercanas, la segunda mitad del setecientos, pero que representarían líneas distintas en la evolución local de los retablos. De una parte el aquí estudiado del Convento Jesús, María y José, el de la ermita de la Virgen de los Remedios ${ }^{39}$ de 1791 y el rococó de la iglesia conventual de las clarisas de 177440 .

Cuando entráramos en el recogimiento monacal que respira toda la iglesia carmelita y acabáramos ante el retablo mayor y su escondida cámara, tendríamos presente la reflexión del carmelita Juan de la Cruz cuando en su obra Subida al Monte Carmelo, al hablarnos de los lugares santos, apunta que en este mundo manejado por lo material, existen sitios como este, donde lo sagrado se hace presente, y surgen los "espacios de trascendencia".

Con toda esta carga ideológica y metafísica, los artistas encargados de la obra plantearon toda esta maquinaria teatral ${ }^{41}$, con la que hacían surgir las imáge-

\footnotetext{
36 JUNQUERA, J. J.: "El arte en la España del siglo XVIII. La escultura" en El Siglo de las Luces. Ilustrados, neoclásicos y académicos. Historia del Arte Español, T. VIII, Edt. Planeta, Barcelona, 1996, pág. 71. Teniendo en cuenta que ambos talleres fueron tremendamente productivos, su influencia y seguidores se hicieron legión por toda la comunidad.

37 RODRIGUEZ DE LA FLOR, F.: Barroco. Representación e ideología en el mundo hispánico (1580-1680), Madrid, Cátedra, 2002, págs. 115-117.

38 OSUNA: Tercer Abecedario, Tratado 6, cap. 3.

39 SÁNCHEZ LÓPEZ, J. A.: "Oportunismo político e instrumentalización de un patronato mariano. La ermita de Los Remedios en Vélez-Málaga y sus pinturas murales", Boletín de Arte, $n^{\circ} 24$, Universidad de Málaga, 2003, pág. 482.

40 GALISTEO, J. y otros: "Patrimonio artístico: Memoria y realidad de una clausura seráfica” en PEZZI CRISTÓBAL, P. (directora): Las Claras de Vélez. Quinientos años de presencia en la ciudad, Vélez-Málaga, 2003, págs. 262-266

41 RODRIGUEZ G. DE CEBALLOS, A.: “El retablo barroco”, op. cit. El autor incide en la utilización reitera-
} 

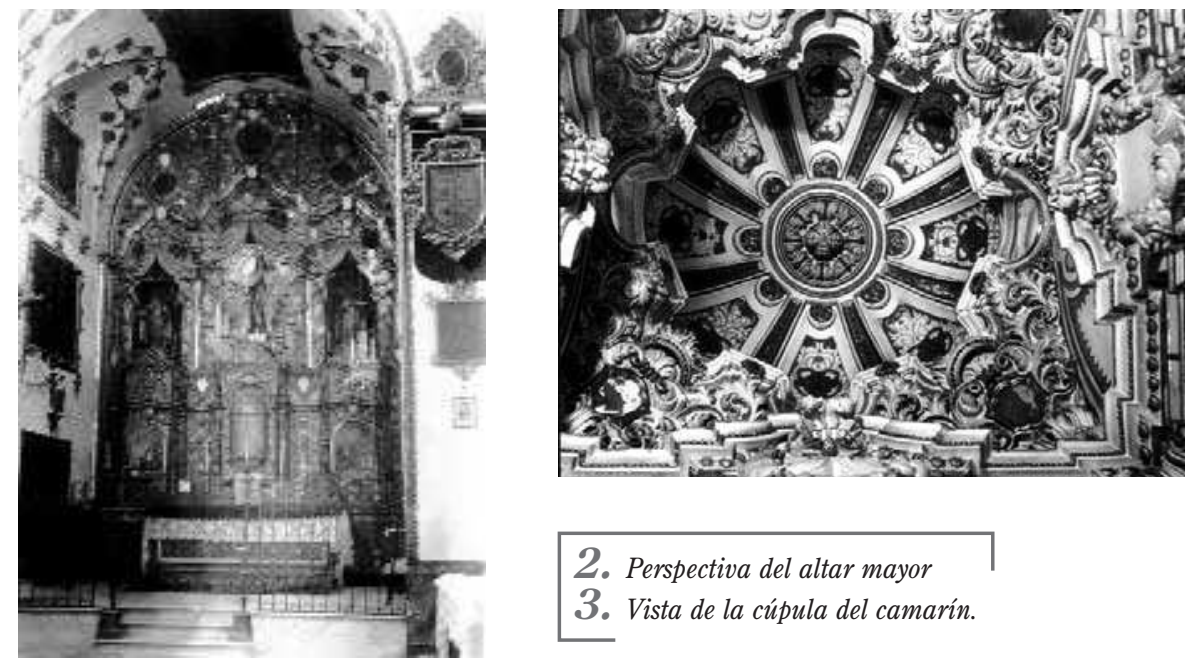

\section{Perspectiva del altar mayor}

3. Vista de la cúpula del camarín.

nes como en los escenarios de la ópera y los dramas tan propios y del gusto de aquella época 42 pues todo el cuerpo central emula una gran galería de la que cuelgan amplios cortinajes de telón, que simulan descorrer mágicamente una compañía de angelitos tramoyistas, sacando a escena a las imágenes de los protagonistas de la reforma de los descalzos, San Juan y Santa Teresa, compartiendo la representación con la "actriz" protagonista de la historia del Carmelo, la Santísima Virgen, que centra la embocadura principal del escenario.

El Carmelo es considerada como una orden eminentemente mariana, como atestiguan multitud de citas de la documentación medieval ${ }^{43}$ son dedicadas normalmente a la bienaventurada Virgen María, igual que aquella primera capilla que los eremitas del desierto levantaron en el Wadi'ain es-Siah, junto al lugar de la fuente de Elías en los remotos inicios en tierras palestinas. Por ello, María es llamada "Mater et Decor Carmeli", pues sus frailes la tienen por Patrona y madre considerada la

da en el Barroco y en especial en la fábrica de retablos, de recursos sacados del teatro, con el objetivo de aumentar el efectismo y la emotividad que se perseguía con las obras de arte. Se usaban efectos de luz, telones móviles, transparentes, autómatas, trampantojos o todo tipo de mecanismos como los ostensorios giratorios para la exposición del Santísimo, y demás trucos y tramoyas de la escenografía con los que atraían a las gentes hacia lo religioso y lo sagrado.

42 En la decoración pictórica y escultórica de este templo de Vélez-Málaga, hemos percibido una fuerte presencia de elementos, motivos y soluciones artísticas relacionadas con el mundo teatral, los cortinajes, los trampantojos, los efectos ópticos, la gesticulación de las figuras, el efectismo y la sorpresa, etc., con lo que confirmamos la estrecha relación que en el mundo barroco de la Edad Moderna tenían todas las manifestaciones artísticas. OROZCO, E.: El teatro y la teatralidad del barroco, págs. 89 y ss.

43 Esta referencia a la consagración mariana de la orden se desprende desde la misma bula de Urbano IV de 1283, en la carta del General Pedro de Millán pidiendo la protección del rey inglés Eduardo I en 1282, en el Capítulo General de 1287 o en otra bula papal de Clemente V que empieza reconociendo "Vuestra santa orden, divinamente instituida por inspiración divina, en honor de la Bienaventurada Virgen María, la gloriosa Virgen,..." MARTÍNEZ CARRETERO, I.: “EI Carmelo...”, op. cit., págs. 29, 32 y 33. 
Hermosura del Carmelo cuya denominación oficial es la de Orden de Hermanos de la Bienaventurada Virgen María del Monte Carmelo.

Su presencia en los conventos carmelitas es permanente, embriagadora, se la percibe y siente en todo, pues la tienen como modelo. Sus misterios de Virginidad, su Concepción Inmaculada o el de su Maternidad divina, son predilectos en esta orden que los sintetiza haciéndola su ideal de vida cotidiana, aspirando cada fraile, monja o terciario carmelitano a construir su actividad diaria con su pureza de corazón, su deseo de unión con Dios. Aplicando el principio del doble espíritu de San Elías, hacer como la Virgen hizo, primero escuchar la Palabra de Él44, luego hacer su voluntad.

Además interpretamos la presencia de la imagen de María junto a los santos carmelitas cubiertos por las telas de los doseles del retablo, como si fueran las caídas de un palio y lo relacionamos con dos composiciones muy difundidas en los carmelos andaluces. De una parte el tema del Pallium Eliae Spiritus por el que el profeta eremita, en su ascenso al cielo deja caer sobre el Carmelo su legado espiritual arrojando su manto sobre los santos y santas de la orden. Así lo encontramos en el lienzo anónimo de San Cayetano de Córdoba 45 . Pero se nos antoja más evidente aun, dentro de las alegorías carmelitanas la continuación de la versión medieval de la Santísima Virgen como Madre de Misericordia, quien recoge bajo el amparo de los pliegues de su manto a esta orden. El tema queda desarrollado en numerosas versiones en varios templos carmelitas de localidades de nuestra región como en Aguilar de la Frontera, Córdoba capital, o en el Santo Ángel sevillano46. Del mismo modo que en estos ejemplos las ampulosidades de las cortinas que cuelgan del retablo manejados por los angelotes escenógrafos, parecen querer desplegar sobre las cabezas del público situado en la iglesia a los pies de María, su capa protectora cobijándolos.

Estos temas alegóricos muy frecuentes en las casas carmelitas como indicábamos, bebían de fuentes grabadas que permitían difundir los tipos, de ahí los préstamos iconográficos que se encuentran. Citamos como ejemplo y esta vez incorporando en exclusiva a Santa Teresa como madre que protege con su capa a sus hijos e hijas, el grabado de la portada del libro Idea de la vida teresiana publicado en Amberes a principios del siglo XVII sobre los grados de la vida religiosa en el Carmen como estados de perfección, en el que la Fundadora cubre a sus frailes y monjas 47 o en la versión pictórica conservada en las Carmelitas de Santa Teresa de Jaén, donde la Santa Madre cubre de igual forma a los miembros de la familia Palomino de Ulloa, fundadores de esta casa jienense descalza, que fueron religiosos y religiosas de la orden 48 .

44 DOBAdo fERNÁNDEZ, J.: "Iconografía del Carmelo en Andalucía" en AA.VV.: Decor Carmeli. El Carmelo en Andalucía, Córdoba, 2002, pág. 164.

45 DOBADO FERNÁNDEZ, J.: “Iconografía...”, op. cit., pág.159.

46 Ibídem., pág. 162.

47 SEBASTIAN, S.: "Iconografía de la vida mística teresiana. Homenaje en el Cuarto Centenario”, Boletín del Museo e Instituto Camón Aznar, n 10, 1982.

48 DOBADO FERNÁNDEZ, J.: "Catálogo de la exposición Decor Carmeli" en AA.VV.: Decor Carmeli. El Carmelo en Andalucía, Córdoba, 2002, págs.246-247. 


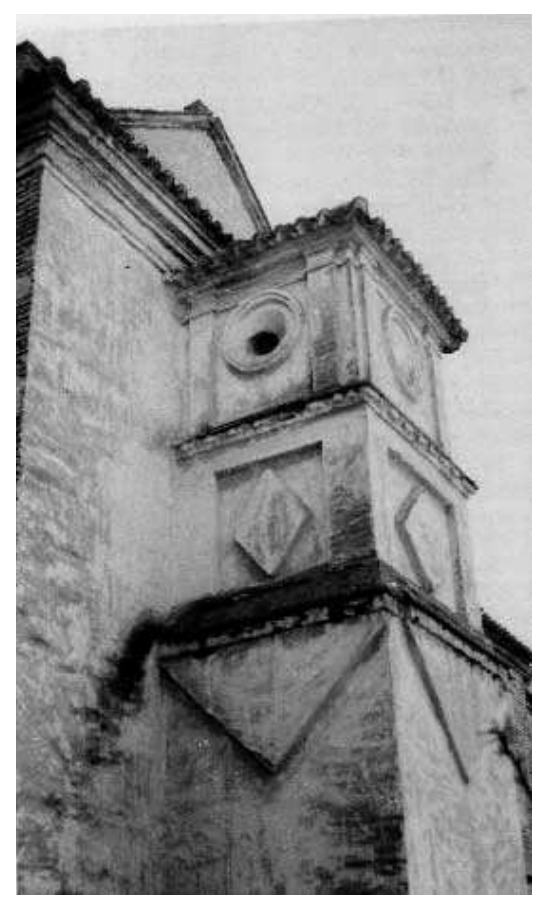

4. Camarín (exterior).

\section{EL CAMARÍN.}

Por toda esta dedicación mariana, en el fondo de nuestro templo, toma cuerpo un espacio trascendente, escondido y recóndito, pero hacia el que apunta todo el conjunto para guardar como en un cofre de tesoros, la joya, Decor Carmeli, de estas monjas, su Patrona y Madre, la Virgen María. No es otro que el camarín.

Se quejaba Jesús Romero en su breve aproximación al fenómeno de los camarines antequeranos 49 de que la historia del arte no había aún valorado suficientemente la entidad de estas construcciones y la importancia de su significado. Continuaba en su intento revalorizador constatando su papel de "envoltura mágica y sobrenatural" en el que la piedad de los siglos XVII y XVIII hispánicos guardaba semiocultas las imágenes de Vírgenes y Santos de incalculable poder religioso y taumaturgia que rozaba en el fetichismo. Distanciábanlas así no de forma física sino más bien mental o idealmente de los devotos que difícilmente accedían a ellas.

Estas originales creaciones arquitectónicas tan andaluzas, siguiendo en la línea de lo anterior, respondían a la vivencia que las personas de aquellas centurias hacían de su religiosidad, muy marcada por la necesidad de comunicación directa con la divi-

49 ROMERO BENITTEZ, J.: “Camarines antequeranos del siglo XVIII”, Jábega, № 13, Málaga, 1976, pág. 25. 
nidad, con la que pretendían tomar contacto casi de forma física, con los sentidos más que con la mente, como en anteriores párrafos adelantamos. El hombre barroco quiere sentir directamente que habla con Dios, anhela su proximidad. Establece con ella un trato íntimo, de tú a tú y desea sentir el soplo de su presencia. De ahí la proliferación de los camarines como auténticas casas donde habitaban las imágenes sagradas, a quienes se visitaba o acudía para tratar con ellas personalmente.

Cuando el ingenuo pero sincero devoto pretende esta familiaridad con lo numinoso, descubre lo lejano e inaccesible del espacio donde mora su imagen, pues la aparatosidad barroca ha creado en torno a él una parafernalia sobrecogedora e intimidatoria, conjugando todo un dispositivo lumínico con espejos, oros, tallas y ventanas ocultas que la envuelven haciendo de ella algo inalcanzable, reluciente e insondable. De este modo, hechizado por semejante despliegue escénico ininteligible, el devoto entabla su sumisa oración, alcanza el éxtasis, siente y palpa lo divino, regodeándose de la gracia que la imagen vierte sobre su espíritu. Dicha talla es, por tanto para él, un "ídolo visible y muy próximo a la vez, distante e intocable de hierática e imponente majestad" 50 .

Así, como pabellón primoroso de un palacio principesco, se levanta en la iglesia este habitáculo. Con su planta cuadrada, con cubierta y ornato cargados de lujo decorativo, construyeron las monjas para su soberana, María Regina Coeli, este recinto para tan grande señora. Íntimo, privado, secreto, es un joyel para custodiar a esa gema.

En este receptáculo donde se materializa la majestad de la Virgen María, se eleva una cúpula gallonada de ocho gajos segmentada por varios nervios que nacen de un rosetón central para bajar hasta apoyar en la cornisa de perfiles polilobulados que sostienen las cuatro trompas. Por éstas trepan ramos vegetales de hojarasca talladas en yeso con volúmenes carnosos en tonos grises y volutas doradas que enmarcan sendos espejos en cada esquina, rematados con una corona.

Cada uno de los muros de este espacio cuadrado aparece policromado, ligeramente oculto bajo una capa de pintura, simulando un zócalo de placas marmóreas cercanas a las que se han restaurado en el Camarín de la Virgen de la Piedad de esta misma ciudad. Se rematan tales lienzos con un entablamento perimetral recorrido por bandas de ovas, rosarios de gotas y una línea de espejos rectangulares, muchos de ellos perdidos. Sus perfiles son distorsionados en su centro y ángulos por unas grandes placas de silueta movida con curvas, contracurvas y volutas laterales, que cae todo como faldón de una exuberante masa vegetal que enmarca unos huecos en los que se encastraron lienzos hoy desaparecidos. Sobre ellos subía un penacho vegetal con venera, envuelto en la continuación mixtilínea del entablamento. Sobre estas formas, conectándolas con las cuencas del lobulado cornisamiento de la bóveda en el hueco donde se abren las tres claraboyas que iluminan la estancia, se disponen otros espejos ovales enmarcados en vegetales tallados en madera dorada que reflejarían la luz de la ventana opuesta.

50 BONET CORREA, A.: Andalucía Barroca, Edt. Polígrafa, Barcelona, 1978, págs. 285-288. 
Alegran y enriquecen este joyero, rosas y girasoles de madera dorada de simbolismo tan mariano al igual que los espejos, tremendamente recurrentes tanto aquí como en el retablo ${ }^{51}$ y la policromía y cromatismo conseguido por la combinación entre la grisalla, el dorado y las tonalidades rojas y azules.

Por la naturaleza de las yeserías la Profesora Rosario Camacho se permitió situar esta decoración en el primer cuarto del siglo XVIII52. La fecha de consagración de la iglesia según las actas del cabildo de la ciudad en 1745 nos hacen cuestionar tal datación y pensamos que este camarín estaría muy emparentado con el dedicado a Jesús Caído en la iglesia del antiguo convento de Carmelitas Descalzos de Belén en Antequera, casa con la que seguro mantenían las carmelitas veleñas buena comunicación. El tallado, policromía y dorado del camarín antequerano se debe a un hermano lego de la orden entre 1742 y 1744, fray Manuel de la Cruz ${ }^{53}$ y sus detalles se podrían relacionar con trabajos en la parroquia del pueblo sevillano de Herrera y en Écija, ciudad donde trabajó un importante círculo de estuquistas 54 .

Al exterior trasero de la iglesia se adosa esta edificación que estudiamos, pero que desde el interior apenas se percibe su existencia y sorprende con lo complejo y recargado de su adentro, cómo fuera encontramos un sobrio y sencillo cubo ideado con un carácter especial a modo de camarín-torre. Arranca desde el suelo a semejanza del mucho más depurado del Santuario de la Virgen de la Victoria de Málaga y está más hermanado con el de la parroquia de Comares o el de la de EI Borge, ambos de esta misma comarca 55 . Con estos dos y con la fachada de la ermita de San Sebastián de Mijas comparte la concepción decorativa que los adorna por medio de placas geométricas adosadas, pormenorizadas en el caso veleño, con figuras triangulares en el piso inferior, rombos enmarcados en el tramo intermedio y en el último las tres ventanas en forma de óculos abocinados abiertos entre pilastras que sustentan el tejadillo a cuatro aguas y que vimos antes que daban luz a la mística teatral que representa en su seno.

Finaliza pues aquí esta homilía carmelita, por medio de la cual el clero pretendió, sirviéndose de las artes, inmortalizar en las paredes el modelo de actuación mística y piadosa que prodiga esta orden, que tomando como patrón a su legendario fundador Elías, condensa el camino hacia el encuentro con la divinidad en la bataIla y el trabajo activo defendiendo las leyes y principios de la Iglesia de Roma mientras se practica el recogimiento de la meditación abandonando con nuestras mentes y espíritu ese mismo mundo terrenal en el que se debe combatir.

51 La Virgen es como el espejo que refleja la luz y no se daña, permanece casta, sin mancha y por eso es el Espejo de la Justicia divina. El espejo no engaña y muestra todo tal cual es. SEBASTIAN, S.: Contrarreforma y barroco..., op. cit., págs. 211-212.

52 CAMACHO MARTÍNEZ, R.: Málaga barroca..., op. cit., pág. 486.

53 ROMERO BENÍTEZ, J.: Guía artística de Antequera, Antequera, 1989, pág. 136

54 ROMERO BENÍTEZ, J.: "Camarines antequeranos...", op. cit., pág. 27.

55 CAMACHO MARTÍNEZ, R.: Málaga barroca..., op. cit., págs. 125, 196-197 y 397. 
En esta iglesia conventual de Jesús, María y José de Vélez-Málaga desde el siglo XVIII se lanza un alegato de la experiencia mística y de la lucha espiritual en la vida religiosa. Además como en tantos y tantos templos y recintos religiosos de la Edad Moderna, haciendo acopio de todo tipo de recursos sacados de todas las artes, fusionando arquitectura con música, poesía con escultura o pintura con teatro, las monjas del Carmen asumen las enseñanzas de San Juan de la Cruz que tanto emocionó y edificó a sus religiosos con los recursos teatrales y emplean la imagen dispuestas como en la escena teatral para mover a la devoción.

De este modo descubrimos así en este conjunto la gran carga simbólica que late en las realizaciones del Barroco hispano y si ponemos hoy oído a sus ecos, resonará la plática de aquel fraile que dijimos al principio, porque ante tales obras aun cuando las contemplemos como público, en palabras del profesor Orozco ante el Juicio Final de Miguel Ángel 56 , no podemos quedar indiferentes pues somos un término vivo en la composición, que nos pide desde los muros de las bóvedas que "la contemplemos, no como críticos o amantes de arte, sino como cristianos".

56 OROZCO, E.: Mística, Plástica y Barroco, Madrid, 1977..en Boletín de Arte, n 30, Departamento de Historia del Arte, Universidad de Málaga, 2009, págs. 
